УДК 94 (477) «1932/1933» (093)

DOI: https://doi.org/10.33782/eminak2020.3(31).457

\title{
ПИТАННЯ ДОСТОВІРНОСТІ СЕЛЯНСЬКИХ МЕМУАРНИХ ДЖЕРЕЛ У ВИСВІТЛЕННІ ПОДІЙ ГОЛОДОМОРУ 1932-33 РОКІВ
}

\author{
Олексій Алєксєєв \\ Запорізький національний університет (м. Запоріжжя, Україна) \\ e-mail: oleksijalekseev79@gmail.com \\ ORCID: https://orcid.org/0000-0002-5142-1484
}

Розглянуто питання достовірності відомостей викладених у селянських мемуарних джерелах стосовно подій Голодомору 1932-1933 років в Україні. Було вивчено рівень можливостей із залучення до комплексних історичних досліджень селянських мемуарів як самостійного історичного джерела. Визначено фактори впливу достовірність мемуарних текстів: авто-цензура, аберації різних видів, вплив соціокультурного середовища тощо. Запропоновано схему класифікації селянських мемуарних джерел за групами, відповідно до їх внутрішніх особливостей та ознак.

Ключові слова: Україна, СРСР, хлібозаготівлі, Голодомор 1932-1933 років, історичні джерела, мемуари, селяни, колгоспники

В історії XX століття Голодомор 1932-1933 років посідає особливе місце, адже став першим штучним голодом в Україні, страшним злочином радянської влади проти українського народу. Масове знищення українського селянства було свідомим терористичним актом здійсненим сталінським режимом, який ставив собі за мету зламати опір українського суспільства на шляху становлення більшовицької системи у країні.

Україна пройшла тривалий шлях відновлення національної пам'яті про цю тра-

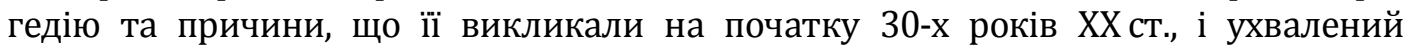
28 листопада 2006 р. Верховною Радою України Закон України «Про Голодомор 1932-1933 років в Україні» став закономірним актом, який визначив події 19321933 років в Україні, що призвели до масової загибелі людей - геноцидом українського народу. Законом зазначається, що Голодомор 1932-1933 років, став наслідком цілеспрямованих злочинних дій тоталітарного репресивного сталінського режиму, спрямованих на масове знищення частини українського й інших народів колишнього СРСР1.

За оцінками істориків, голод 1932-1933 років забрав життя від трьох до семи мільйонів людей. Спираючись на данні матеріалів перепису населення 1937 р., можемо говорити про близько шість мільйонів лише прямих втрат у період Голодомору 1932-1933 років ${ }^{2}$. Це лише суха статистика, проте за нею стоять долі конкретних людей і трагедії їх родин, які неможливо передати лише витягами з урядових постанов і зведеними таблицями з кількістю загиблих. Розуміючи це, дослідниками була проведена значна робота зі встановлення імен і прізвищ людей, що загинули від голоду в 1932-1933 рр. Крім того, було зібрано великий обсяг усних спо-

\footnotetext{
1 Закон України «Про Голодомор 1932-1933 років в Україні» // Відомості Верховної Ради України. 2006. № 50. С. 504.

2 Марочко В. Голодомор 1932-1933 рр. Київ, 2007. С. 54.
} 
гадів людей, що стали свідками голоду.

Основу вивчення питання Голодомору 1932-1933 років за часів незалежної України заклали у своїх працях Ю. Шаповал 3 , авторське тріо у складі Г. Касьянова, В. Даниленка та С. Кульчицького слідники із Запоріжжя, зокрема Ф. Турченко, який розвінчав одразу кілька радянських міфів про події Голодомору 1932-1933 років; довів, що голодом були охоплені не лише села, а й міста України. Ним було проведено розрахунки коефіцієнту смертності, які показали зростання смертей у період 1932-1933 рр. по селах приблизно у 6 разів, по містам (Василівка, Мелітополь) у 3 рази ${ }^{5}$

Свідчення очевидців трагедії Голодомору, як історичне джерело, досліджувала старший науковий співробітник Інституту історії України О. Велесова6. У царині збору, публікації свідчень очевидців та їх аналізу активно працювала професор Г. Капустян ${ }^{7}$. Особливе місце серед досліджень усної історії Голодомору 1932-1933 років займає монографія Т. Боряк (Інститут історії України), в якій представлено спогади свідків про вилучення всіх їстівних запасів під виглядом хлібозаготівель ${ }^{8}$.

Значний обсяг фактичного матеріалу було зібрано учасниками історикоархеографічних експедицій ЗНУ. Отриманні дані по болгарським селам Запорізької області дозволили вченим ЗНУ В. Мільчеву та Ю. Іріоглу дійти висновку, що лихо охопило весь регіон Південно-Східної України незалежно від національного походження людей 9 .

Якщо говорити про сучасний стан розробки теоретичних і методологічних проблем української мемуаристики, то можемо констатувати фактичну відсутність грунтовних монографічних досліджень. Разом із цим, у сфері мемуаристики працювали такі дослідники, як Г.Стрельский, Р. Пиріг, С. Макарчук, С.Білокінь, Н. Миронець, І. Войцехівська й ін. ${ }^{10}$

Таким чином, на сьогодні маємо грунтовний історіографічний та археографічний доробок за проблемою вивчення питання Голодомору 1932-1933 років, дослідниками було зібрано та проаналізовано значний масив історичних джерел, зокрема особового походження. Було приділено увагу виробленню методологічних напрацювань у галузі аналізу історичних джерел, розробці класифікаційних схем.

У джерельній базі з історії Голодомору 1932-1933 років в Україні джерела осо-

\footnotetext{
3 Шаповал Ю. Голодомор 1932-1933: втрата та винайдення: з публ. архів. док. // Дзеркало тижня. 2006. 18-24 листопада (№ 44). С. 21.

4 Даниленко В.М., Касьянов Г.В., Кульчицький С.В. Сталінізм на Україні: 20-30-ті роки. Київ: Либідь, 1991. 344 с.

5 Турченко Ф.Г. Пізнати правду... // Голодомор 1932-1933: запорізький вимір. Запоріжжя: Просвіта, 2008. С. 6-22.

${ }^{6}$ Веселова О.М. Українські збірники документів і матеріалів з питань голодомору. Голод 19321933 років в Україні: причини та наслідки. Київ: Наук. думка, 2003. С. 50-72.

7 Капустян Г. Оцінка Голодомору 1932-1933 рр. в Україні в документах усної історії. Голодомор 1932-1933 років в Україні: причини, демографічні наслідки, правова оцінка: матеріали міжнар. наук. конф. Київ, 25-26 вересня 2008 р. / відп. ред. І.Р. Юхновський. Київ, 2009. С. 169-189.

8 «І чого ви ще живі?» / упоряд. Т. Боряк. НАН України. Інститут історії України. Київ: ТОВ «Видавництво «Кліо»«, 2016. 720 с.

9 Мільчев В.І., Іріоглу Ю.О. «Усні історії» таврійських болгар як джерело дослідження голодоморів 1932-1933 та 1946-1947 років // Голодомор 1932-1933: запорізький вимір. Запоріжжя: Просвіта, 2008. C. 208-230.

10 Любовець Н.І. Вивчення мемуарів як історичного та біографічного джерела: до історіографії проблеми. // Українська біографістика. 2010. Вип. 7. С. 94-95.
} 
бового походження посідають важливе місце, зокрема до дослідження питання активно використовуються спогади безпосередніх свідків трагедії. Історичною наукою було залучено значний обсяг як матеріалів усної історії, так і мемуарних джерел різних соціальних верств населення. Проте, звертає на себе увагу, незначне залучення до вивчення даної проблематики мемуарних джерел верстви, що на собі відчула голод 1932-1933 років - селянства. Таку ситуацію можемо пояснити тим, що у джерелознавчих та історіографічних дослідженнях мемуаристика, зокрема, та що стосувалася особових джерел селян, як правило, не потрапляла до аналізу дослідників як самостійна тема.

На жаль, до часу коли стало можливим повноцінне дослідження Голодомору 1932-1933 років, вдалося дожити лише небагатьом свідкам тих подій. Тому важливим $є$ проведення комплексного аналізу джерел особового походження - щоденників, автобіографій і мемуарів людей, які висвітлюють трагедію Голодомору, зокрема селянських мемуарних джерел. Мета пропонованої розвідки, полягає у дослідженні інформативних можливостей селянських мемуарів, з'ясуванні їх особливості, у порівняні з мемуарами інших соціальних верств населення, визначенні рівня інформативності та достовірності.

Цінність мемуарів і щоденників полягає в тому, що дозволяє виокремити з них інформацію соціально-психологічного змісту, яка відсутня в інших видах історичних джерел. Їх дослідження дає можливість не лише відтворити або уточнити вже відомі факти, а й глибше зрозуміти саму історичну епоху та їі колорит. Крім того, джерела особового походження часто містять інформацію, якої немає в інших джерелах, вони передають настрої окремих людей і соціальних груп.

Залучення до дослідження питань Голодомору селянських мемуарів дозволяє виокремити новий пласт історичної інформації, від безпосередніх учасників подій, які перенесли голод 1932-1933 рр. вже в осмисленому віці, маючі власні родини, дітей і сформовані світоглядні погляди. Такі свідчення додають автентичності до картини історії та дозволяють простежити впливи радянської освіти й пропаганди у такому болючому питанні як Голодомор.

На думку автора логічним є вивчати селянські мемуари при розгляді подій Голодомору 1932-1933 років за проблемним принципом, відповідно до напрямків дослідження:

1. Визначення рівня розуміння селянськими авторами причин, що призвели до Голодомору 1932-1933 років, виявлення можливих впливів світоглядних переконань авторів і ролі пізніших нашарувань, що відбилися на викладені ними причини Голодомору.

2. Дослідження інформативних можливостей селянських мемуарних джерел у питанні подій Голодомору 1932-1933 років. Виявлення спільних і відмінних рис селянських особових джерел.

3. Означення рівня впливу епохи на викладення фактичного матеріалу. Питання повноти, достовірності, приховування інформації або недомовок в умовах радянської тоталітарної системи.

4. Вплив самоцензури на викладення подій Голодомору 1932-1933 років селянськими авторами. Встановлення внутрішніх і зовнішніх факторів виникнення самоцензури авторів.

5. Аналіз суб’єктивного погляду мемуариста, як додаткового предмета дослідження, з метою пошуку допоміжних даних. 
Однією з причин початку голоду в селянських мемуарах визначаються несприятливі погодні умови та, як наслідок, недостатня врожайність зернових культур. Саме на це, як на основну причину, вказує одразу кілька авторів мемуарів.

У мемуарах Данила Коншина, жителя с. Більманка (Більмацький район Запорізької області) знаходимо, що 1932 р. виявився неврожайним, внаслідок посухи, яка охопила не лише район, але й всю область ${ }^{11}$.

Підтверджує версію про неврожайний рік й уродженка с. Лукашеве (Запорізького району, Запорізької області) Авраменко Діана Іванівна, яка на 1932 р. мешкала у м. Оріхів (Запорізької області) ${ }^{12}$.

Додає подробиць про несприятливі погодні умови Штерев Іван Іванович, селянин с. Інзовка (Приморський район, Запорізької області), він згадує про сильну посуху від якої вигорали рослини і трава, та пилові бурі, що видували посіви ${ }^{13}$.

Інші причини виникнення голоду в Україні у 1932 р. у згаданих авторів не знаходимо. Фактично повторюється пізньорадянська риторика з визначення причин голоду 1932-1933 рр. з вживанням тогочасних словесних формул. Єдиним винятком, $є$ згадка Данила Коншина, у контексті причин виникнення голоду хворобу, що охопила коней і викликала їх масову загибель ${ }^{14}$, що призвело до нестачі тяглової сили на селі.

Про нестачу коней пише у своїх мемуарах Михайло Алексєєв (с. Сіваши Херсонської області), проте він вказує на пряму провину місцевого керівництва та комуністів, а не на хвороби. Він каже, що нестача тяглової сили на селі стала наслідком недалекоглядної політики та зухвалості з боку керівництва колгоспу. Адже місцеві більшовики вважали, що механізація сільського господарства, зокрема запровадження тракторів і комбайнів, вже знаходиться на тому рівні, який би дозволив відмовитись від використання живої тяглової сили на селі15.

Серед причин Голодомору 1932-1933 років вказується бажання центрального керівництва країни прискорити та якомога швидше завершити процес формування колгоспів. Що дозволило б посилити контроль над селянством і викачування максимальних ресурсів із села, перетворивши фактично селян на кріпаків.

Уродженець с. Новогорожене (Баштанський район Миколаївської області) Сергій Сало причиною голоду 1932-1933 рр. називає бажання прискорити процес кооперування хліборобів, загнавши всіх селян у колгоспи. Необхідність завершити створення колгоспів, С. Сало у своїх мемуарах пов'язує також з міжнародною обстановкою, зокрема виникнення у країнах Європи фашистських режимів і мріями радянського керівництва про скору світову революцію. С. Сало відверто каже, що голод було створено штучно, з метою «підстьобнути» хліборобів до масового переходу у колгоспи ${ }^{16}$.

У визначених С. Сало причинах початку Голодомору та визначені штучності його створення ми маємо можливість простежити пізніші нашарування вражень та

\footnotetext{
${ }^{11}$ Коншин Д. Рассказ о своей жизне... / Передмова С. Шевчук. Запоріжжя, 2008. С. 196.

12 Алєксєєв О.О. «Оріхівська справа в долі моєї родини». Запоріжжя, 2009. С. 11, 44.

13 Мемуари та щоденники. Ч. 2 / Упорядники: А. Бойко, В. Мільчев // Джерела з історії Південної України. Т. 9. Запоріжжя, 2006. С. 245.

${ }^{14}$ Коншин Д. Рассказ о своей жизне... С. 196.

15 Мемуари та щоденники. Ч. 1 / Упорядники: А. Бойко, С. Плохій / Передмови: С. Плохій, А. Бойко, В. Чоп, В. Мільчев // Джерела з історії Південної України. Т. 5. Кн. 2. Запоріжжя, 2005. С. 245.

16 Сало Сергій. Спогади (1899-1946рр.). (Серія «Старожитності Південної України», випуск 24). / Упор.: Білівненко С., Молдавська Т. Київ, 2014. С. 66.
} 
інформації отриманої автором мемуарного джерела. Свідченням цього є, у першу чергу, глибина висновків, що робиться у мемуарах С. Сало та підтверджується можливою датою створення джерела - 1984 рік ${ }^{17}$.

Індустріалізація, як ще одна причина Голодомору 1932-1933 років, знайшла своє відображення у мемуарах Миколи Васильовича Молодика, уродженця с. НовоГупалівка (Вільнянський район Запорізької області). За його споминами у 1932 р. зникли фактично всі товари як у продовольчих, так і в господарських магазинах, ціни різко були підвищенні, а на ринках неможливо було нічого купити.

Микола Молодик згадує, як в 1932 р. батько працював у колгоспі та жив дуже бідно, голодував. Оскільки селяни від колгоспів фактично нічого не отримували, адже держава забирала все, щоб продати за кордон і придбати промислове обладнання для підприємств та електростанцій, які будувались на виконання п'ятирічного плану ${ }^{18}$.

Пов’язує голод з індустріалізацією країни у своєму щоденнику селянин із Запоріжжя Іван Ярошенко, який працював на будівництві промислових об'єктів м. Запоріжжя i, як такого, голоду не знав, а відчував лише нестачу продуктів. У своєму щоденнику він висловлює сподівання, що із завершенням процесу індустріалізації країни відбудеться нормалізація у сільському господарстві ${ }^{19}$.

Знаходимо свідчення і про те, що з самого початку керівництвом ставилися нереальні плани на хлібозаготівлі, які повинні були виконати колгоспи. Михайло Алексєєв у своїх мемуарах згадував, що перед збором врожаю, навесні 1932 р. норма врожайності, та відповідно норма, яка повинна була бути здана державі, спускалася з гори без погодження або консультацій із колгоспниками. Він зазначає, що селяни розуміли неможливість виконати ті плани на хлібозаготівлю, які спускали у колгоспи, але особливо з керівництвом не сперечались. Адже розуміли особисті наслідки у разі незгоди з вищим керівництвом 20.

Нездійсненність виконання поставлених перед Україною норм з хлібозаготівлі призвела до посилення тиску на селян з боку центральних органів державної влади. У країні почали шукати винних і вже у січні 1932 р. в окремих округах розпочалися судові процеси над тими, хто на думку влади зривав хлібозаготівельну компанію. Намагання пояснити ситуацію та донести до керівництва держави заяви про неможливість виконання планів з хлібозаготівлі наштовхувались на відверту ворожість і нерозуміння з боку уряду СРСР. Так, Молотов у газеті «Правда» (1932 р.) назвав «антибільшовицькими» спроби звалити вину за невдачі на нереалістичні плани і додав: «Не буде поступок чи хитань у питанні виконання завдання, поставленого партією та радянським урядом»21.

Підтвердженням цих подій, коли неможливість виконати план з хлібозаготівлі призвела до хвилі репресій і посилення тиску на селян, знаходимо у селянських мемуарах. Михайло Алексєєв у своїх споминах про збір врожаю у 1932 р. повідомляв, що поставлений державою план вдалося виконати лише на 60 відсотків. Колгоспне керівництво зрозумівши, що нема як виконати плани 3 хлібозаготівлі та

17 Сало Сергій. Спогади... С. 3.

18 Мемуари та щоденники. Ч. 1 ... С. 345.

19 Ярошенко Иван Иванович. Дневники и записи // Сайт «Прожито». URL: https://www.prozhito.org/notes?date=\%221932-01-01\%22\&diaries=\%5B2242\%5D

20 Мемуари та щоденники. Ч. 1... С. 602.

21 Конквест Р. Жнива скорботи. Колективізація і голодомор. Київ, 1993. С. 183. 
можливу власну відповідальність за зрив поставлених перед ними завдань, почало проводити політику з пошуку винних серед селян, звинувативши їх у крадіжках державного зерна й ухиляння від виконання поставлених норм. Як наслідок, створення комісій з вилучення зерна у селян 22.

Крім того, партійне керівництво на місцях вдавалося і до відвертих погроз і шантажу. Так селянин с. Леб'яжого (Чугуївський район Харківської області) Нестор Білоус у своєму щоденнику повідомляв, як його викликав бригадир колгоспу та вимагав здати особисте зерно, погрожуючи у разі незгоди конфіскувати все його майно та продати для покриття недостачі плану з хлібозаготівель. Нестор Білоус цитуючи бригадира колгоспу каже: «Все равно бедняк и середняк, а хлеб давай» 23 .

Щоденник Нестора Білоуса дає нам чудову можливість провести порівняльний аналіз з мемуарами Сергія Сало. Обидва ці автори є мешканцями села, відверто описують події Голодомору та критично ставляться до радянської влади, проте не дивлячись на таку подібність, мають кілька принципових для нас відмінностей. Н. Білоус, на відміну від С. Сало, не намагається аналізувати причини голоду 19321933 рр. та не робить узагальнюючих висновків у своєму щоденнику. 3 одного боку, ми можемо сказати, що все ж Н. Білоус був селянином, на відміну від С. Сало, який хоч і походив із селянської родини, натомість був сільським вчителем, а отже мав кращу освіту. Проте визначальним скоріше $\epsilon$ час створення документу і вид джерела. Н. Білоус вів щоденник, занотовуючи події та роздуми відповідно до реального часу. С. Сало писав мемуари-спогади маючи можливість охопити минулі події з висоти років та маючи змогу проаналізувати вже більш широкий спектр інформації. Щоправда не можемо забувати про тиск репресивної машини, який не був однаковим у часи створення даних джерел і теж міг впливати на стиль викладання розглянутих авторів.

3 метою посилення тиску на селян 7 серпня 1932 р., за ініціативою Й. Сталіна, упроваджується постанова, відповідно до якої так зване «розкрадання колгоспного майна» карається розстрілом, або позбавленням волі терміном не менш ніж на 10 років $^{24}$.

18 листопада 1932 р. в Україні запроваджуються натуральні штрафи. У господарствах, що «заборгували» за нереальними планами хлібозаготівель, конфісковують усе продовольство й худобу 25.

Щоб провести у життя завдання партії по виконанню норм хлібозаготівлі, було вирішено провести мобілізацію місцевих сільських активістів, на допомогу яким прислати міських комуністів і комсомольців. Створювалися спеціальні загони, яким ставилась мета відібрати все зерно й інші продукти харчування, з метою покривання недостачі хлібозаготівлі.

Інформацію про діяльність бригад активістів знаходимо у селянських мемуарах. Так С. Сало згадує, що по дворах почали ходити «комісії по із'ятію ізлішков», які складалися з членів «Комнезаму», комсомолу та членів партії. Комісії обшукували

\footnotetext{
22 Мемуари та щоденники. Ч. 1... С. 602.

23 Белоус Нестор. Дневники и записи // Сайт «Прожито». URL: https://www.prozhito.org/notes?date=\%221932-01-01\%22\&diaries=\%5B84\%5D

24 Верстюк В., Тиліщак В., Юхновський І. Геноцид українського народу 1932-1933. Київ, 2008. C. 13-14.

25 Мейс Дж. Політичні причини Голодомору в Україні $\quad$ (1932-1933pp.). 2004 p. URL: http://ekmair.ukma.edu.ua/handle/123456789/447
} 
хату, комору, по городах ходили з щупами, вишукуючи приховане зерно 26.

Бригади ми зустрічаємо й у мемуарах Михайла Алексєєва. Судячи з того, що він називає прізвища людей, які входили до комісій, що мали вилучати «ізлішки», ми знаходимо підтвердження що до їх складу входили переважно місцеві активісти. Комісії вилучали у селян той хліб, який вони отримали (15\%) від того, що було здано державі. Проте, це не вирішило проблеми недостачі та комісії перейшли до вилучення й іншого майна27.

Знайшли своє відображення у селянських мемуарах і факти масової загибелі людей від голоду. Сергій Сало у своїх мемуарах згадував, як він, працюючи у сільській школі, особисто став свідком масового захоронення людей, що померли від голоду в його селі: «Дивлюсь через вікно на вулицю і бачу: літня людина везе тачку, на тачці трупи. Видно руки, ноги, чуть прикриті рядниною. Везуть на кладовище»28.

Підтверджується масова смертність людей від голоду у щоденнику Олександри Радченко, яка у 1930-ті рр. працювала учителькою на Харківщині. Говорячи про факти смертей від голоду у с. Бабки (Харківська область) вона засвідчує, що 24 i 26 квітня 1933 р. у селі померло двадцять дві людини ${ }^{29}$.

Важливим свідком масових поховань людей, що загинули внаслідок Голодомору, став Михайло Алексєєв. Мешкаючи у 1933 р. у с. Петрівка (Херсонська область) поблизу із сільським цвинтарем він особисто бачив поховання людей та у своїх мемуарах вказує не лише їх кількість, а й місце поховання. Так він повідомляє нам, що померли від голоду близько 25 чоловік на день. А місцем їх захоронення стала канава, якою був обритий діючий цвинтар. Вибір канави навколо цвинтаря, як місце останнього спочинку померлих від голоду, було обране, за його словами, у зв'язку із знесиленням людей, в яких вже не було сил на риття могил. Крім того, були й родини в яких не вдавалося вижити жодній людині, вся сім'я померла від голоду та не було кому їх поховати ${ }^{30}$.

Як додатковий пласт мемуарних джерел у питанні Голодомору 1932-1933 років в Україні виділяємо щоденники радянської інтелігенції та службовців, які стали свідками подій. Залучення даних джерел до дослідження дозволяє провести порівняння інформованості та ставлення до голоду 1932-1933 рр. серед різних верств українського населення.

Особливо цікавим у даному контексті є щоденник завідувача відділом культури і пропаганди Ленінського районного партійного комітету м. Києва, члена бюро райкому Дмитра Дмитровича Заволоки, який у лютому 1932 р. обіймав відповідальну посаду у Київській обласній контрольній комісії.

Дмитро Заволока у 1932 р. переживає певне переосмислення своїх життєвих поглядів у зв'язку з подіями на українському селі. Хоча сам він мешкає у Києві та страждає від нестачі продуктів, проте він не голодує, а про події за межами міста він дізнається від своєї матері, мешканки села.

У щоденнику Д. Заволоки, який він назвав «мертвим істориком», простежується

\footnotetext{
26 Сало Сергій. Спогади... С. 66.

27 Мемуари та щоденники. Ч. 1 ... С. 603-604.

28 Сало Сергій. Спогади... С. 67.

29 Голодомор 1932-1933 років в Україні: документи і матеріали / Упор. Р.Я. Пиріг; НАН України. Інт історії України. Київ: Вид. дім «Києво-Могилянська академія», 2007. С. 1023.

30 Мемуари та щоденники. Ч. 1 ... С. 609.
} 
особистий злам від недовіри та іронії на розповіді про голод, що охопив село, до розуміння всієї глибини трагедії. Сам будучи партійцем впевненим у правильності дій комуністичної партії, він довго не міг повірити у розповіді про те, що відбувається на селі. Власну матір, хоч і з певною долею жартівливості, він звинувачує у тому, що вона підпала під ворожу агітацію та повторює різні куркульські «страхи», він відмовляється їй вірити та стверджує, що партія не може допустити голоду на селі.

Однак факти, що стають перед Д. Заволокою, повністю змінюють його світогляд і ми бачимо його трансформацію від вірного партійця до людини, що усвідомлює той злочин, який відбувається на його очах і розуміє відповідальність комуністичної партії за ситуацію в країні, яка призвела до голоду. У своєму щоденнику він закликає бути відвертими перед собою до кінця та визнати, що до голоду призвела комуністична система керівництва, проти якої ніхто не сміє сказати жодного слова $^{31}$.

На відповідальність радянського керівництва звертає увагу у своєму щоденнику поетеса, перекладач Варвара Малахієва-Мирович. Родом з Києва, проживаючи у Москві, вона знала про голод, що охопив Україну і про те, що у скрутному становищі знаходиться її двоюрідна сестра з трирічним онуком. Проте не могла їм допомогти навіть надіславши посилку з харчами, адже з 1 квітня 1932 р. почала діяти заборона на відправку посилок з харчами ${ }^{32}$.

Винуватцем голоду 1932-1933 рр. радянську владу називає у своєму щоденнику 23-річний вчитель семирічки з с. Ферната (сучасна назва - с. Кармалюківка Балтського району Одеської області) Олексій Наливайко. Він повідомляє про нестачу хліба, конфіскацію майна у селян, масовий голод і вимирання цілих сімей. Звертає увагу на брехливість радянської пропаганди, кажучи, що газеті «Правда» більше б личила назва «Брехня». Повідомляє про більшовицьку реакцію на опір, звинувачує комуністичну партію в організації голоду. Заявляє, що вона прирікає селянство на смерть, або висилку в далекі місцевості СРСР.

О. Наливайко, ставши свідком страшних подій Голодомору, у своєму щоденнику приходить до висновку, що необхідно боротися з більшовицьким режимом. Він окреслює для себе план виїхати за межі СРСР і приєднатися до антибільшовицьких організацій з метою боротьби з комуністичною владою у його країні 33 .

Проте, серед мемуарів наукової інтелігенції зустрічаємо і зворотній погляд. Таким прикладом $є$ щоденник викладача з Харкова, переконаного комуніста, вихідця з родини партійної номенклатури Михайла Сінькова. Він не бачив жодної провини з боку радянської влади. М. Сіньков писав, що в голоді та масових смертях винні самі селяни, які не хочуть віддати державі хліб. Стверджував, що серед селянства панують дрібновласницькі настрої та чиниться опір будівництву нового світу. М. Сіньков каже, що хліб у селян $€$ і його більш ніж достатньо, проте вони віддають перевагу загибелі від голоду, згноївши зерно у своїх схованках ніж віддати його

\footnotetext{
31 Голодомор 1932-1933 рр. в Україні за документами ГДА СБУ: Анотований довідник / В.М. Даниленко (відп. упоряд.), Л.Л. Аулова, В.В. Лавренюк. Львів: Центр досліджень визвольного pyxy, 2010.C. 325-326.

32 Малахиева-Мирович Варвара. Дневники и записи // Сайт «Прожито». URL: https://www.prozhito.org/notes?date $=\% 221932-01-01 \% 22 \&$ diaries $=\% 5$ B 484\%5D

33 Файзулін Я. Щоденник учителя, за який дали 10 років таборів // Gazeta.ua. 2017. 30 листопада. URL: https://gazeta.ua/articles/events-journal/_sodennik-uchitelya-za-yakij-dali-10-rokivtaboriv/805029
} 
державі ${ }^{34}$.

Розглянуті матеріали дозволяють зробити висновок, що селянські мемуари несуть у собі риси притаманні більшості аналогічних джерел особового походження. Автори селянських мемуарів, працюючи над своїми творіннями, заздалегідь обирають ту чи іншу позицію, яка відповідає їхнім особистим уявленням. Коли ж подія розходилася з їх світоглядом, або могла виставити автора мемуарів у негарному вигляді, така подія замовчувалася.

Характерною особливістю селянських мемуарів $\epsilon$ те, що вони писалися як розповідь про власне життя, історію родини або краю вже на схилі віку авторів. Адже селянське буття не залишало часу на ведення записів і лише наприкінці життя у них з'явилася можливість творити історію. Поштовхом для написання мемуарів стала Перша світова війна, коли рекрутовані до армії селяни потрапили під вплив офіцерів і мали час вести власний щоденник, зокрема Михайло Алексєєв згадував про те, що вів записи, перебуваючи на фронтах Першої світової війни. Другим поштовхом стало введення загальнообов'язкової освіти у державі. I, нарешті, можливість вийти на пенсію для селян остаточно дала шанс взятися за перо селянському прошарку.

Констатуємо, що у селянських мемуарах простежується чітке уявлення селян про причини Голодомору 1932-1933 років і штучність його виникнення. Щоправда, в окремих мемуарних спогадах зустрічаємо намагання обійти увагою дану тему, а її причини звести до несприятливих погодних умов і неврожаю.

В описі подій 1932-1933 рр. у селянських мемуарах ми також виділяємо два основних напрямки викладення авторами матеріалу. Перший напрямок, це намагання замовчати тему і якщо й згадати про голод 1932-1933 рр., то лише поверхово. Другий напрямок, це досить відверта розповідь про події з викладенням власного бачення та власного розуміння тієї трагедії, що розгорнулася в особистому житті авторів мемуарів.

Відзначаємо, що селянські мемуарні джерела у питанні подій Голодомору 19321933 років цілком достовірні. Деякі з них, як наприклад мемуари Дмитра Коншина, засвідчують лише сам факт голоду, уникаючи подробиць. Інші мемуарні джерела Михайла Алексєєва, Сергія Сало, Івана Штерева, Миколи Молодика дають уже більш розгорнуту картину голоду. Вони розуміють і формулюють у своїх мемуарах причини голоду, описують перебіг подій, зберігаючи причино-наслідкові зв'язки, повідомляють не лише про смерті від голоду в своїх родинах, але й інших людей. Окремо ставимо щоденник Михайла Сінькова, який підтверджує голод, проте винними називає саме селянство.

Не простежуються у авторів значні відмінності у визначенні причин і подій Голодомору в селянських мемуарних джерелах, не дивлячись на географічний фактор. Автори мемуарів підтверджують не лише факт голоду в різних регіонах Південно-Східної України, але його однаковий перебіг та однакову реакцію місцевої комуністичної влади на події.

Звертає на себе увагу той факт, що фактично кожен з авторів мемуарів виділяє для себе свій мотив початку Голодомору 1932-1933 років і не визначає причини комплексно. Така ситуація пояснюється, перш за все, недостатньою інформованіс-

34 «Репресовані» щоденники. Голодомор 1932-1933 років в Україні / Упоряд., вступ. ст., заг. ред. Я. Файзуліна. Київ: Фенікс, 2018. С. 336. 
тю селян про процеси, що відбувалися у центральних органах влади та на місцях, закритістю інформації щодо подій Голодомору в засобах масової інформації. Кожен з авторів визначає причину початку голоду, виходячи з того, яку освіту отримав вже після самих подій, яку інформацію зміг отримати до власних рук, з огляду на особисте враження виходячи з життєвого досвіду.

У розглянутих мемуарах ми бачимо неточності у хронології подій і викладенні фактів. Накладаються на матеріали авторів і пізніші переживання та враження, простежуються впливи особистих ідеологічних переконань.

Так Дмитро Коншин, хоча і не був партійним активістом, але з огляду на його мемуари був прихильником комуністичного ладу, лише поверхово згадує про голод 1932-1933 рр. та вказує на несприятливі погодні умови.

Переконаний комуніст Михайло Сіньков тримає офіційну лінію партії. За його щоденником комуністична партія веде до світлого майбутнього, проте зустрічаються ще дрібновласницькі елементи, які опираються новому життю та голодують із власної вини, не бажаючи підкоритись партійному керівництву.

Натомість Михайло Алексєєв, будучи явно противником комуністичної ідеї, зупиняється на Голодоморі досить детально, фактично звинувачуючи у ньому комуністичний лад. Головним винуватцем Голодомору 1932-1933 років в Україні він визначає особисто Й. Сталіна та його послідовників в особі членів комуністичної партії 35 .

За результатами проведеного компаративного аналізу селянських мемуарів і даних «Національної книги пам'яті жертв Голодомору 1932-1933» вдалося встановити кілька нових імен, що не потрапили до раніше зібраних відомостей і потребують додаткового включення.

Олександр Миколайович Молодик, 1933 р. н., с. Обухівка Дніпропетровської області. Помер від голоду 1933 року. До «Національної книги пам'яті жертв Голодомору 1932-1933 років в Україні. Дніпропетровська область» не включений 36.

Дмитро Рубель, с. Мала Білозерка Василівського району Запорізької області. Помер від голоду 1 травня 1933 р. До «Національної книги пам'яті жертв Голодомору 1932-1933 років в Україні. Запорізька область» не включений ${ }^{37}$.

Штерев Іван Семенович, 49 років. с. Інзівка Приморського району Запорізької області. Помер від голоду 1933 р. До «Національної книги пам'яті жертв Голодомору 1932-1933 років в Україні. Запорізька область» не включений.

Штерев Василь Іванович, с. Інзівка Приморського району Запорізької області. Помер від голоду 1933 р. До «Національної книги пам'яті жертв Голодомору 19321933 років в Україні. Запорізька область» не включений.

Галушко (ім'я не встановлено), с. Петрівське (сучасна назва Благодатне) Білозерський район Херсонської області. Помер від голоду 1933 р. До «Національної книги пам'яті жертв Голодомору 1932-1933 років в Україні Херсонська область» не включений ${ }^{38}$.

\footnotetext{
35 Мемуари та щоденники. Частина 1... С. 609

36 Національна книги пам'яті жертв Голодомору 1932-1933 років в Україні. Дніпропетровська область. Дніпропетровськ: АРТ-ПРЕС, 2008. 1248 с.

37 Національна книги пам'яті жертв Голодомору 1932-1933 років в Україні. Запорізька область. Запоріжжя: Дике поле, 2008. 1080 с.

38 Національна книги пам'яті жертв Голодомору 1932-1933 років в Україні. Херсонська область. Херсон, 2008. 707 с.
} 
При проведенні порівняльного аналізу мемуарів-літописів (щоденники) та мемуарів-спогадів ми бачимо схожість рис та інформаційного змісту у викладені матеріалів. Що свідчить про інформативну достовірність історичних фактів, схожість поглядів протягом часу на описувану проблему як серед селянського стану, так й інших верств населення. У розглянутому комплексі джерел можемо спостерігати зміни у питанні категоричності висновків з певних сумнівів і сподівань на виправлення ситуації на селі в період Голодомору 1932-1933 років (щоденники Дмитра Заволоки, Івана Ярошенка) до покладання повної відповідальності за трагедію на комуністичну партію й особисто Йосипа Сталіна (мемуари Михайла Алексєєва). Бачимо еволюцію від обережного згадування про голод в окремих мемуарахлітописах до відвертої критики вищого керівництва держави у мемуарах-спогадах. Дану зміну пояснюємо отриманням нової інформації, раніше недоступної авторам мемуарів і послабленням радянської репресивної машини.

Звертає на себе увагу відсутність визначальних впливів на викладення матеріалів з огляду на національну ідентичність авторів мемуарів. Так етнічний українець Сергій Сало набагато ближчий у своїх поглядах на події Голодомору 19321933 років до етнічного росіянина Михайла Алексєєва, ніж до іншого українця Івана Ярошенка. Отже, можемо говорити про домінування соціального над національним та неартикульованість національних ідентичностей на селі протягом більшої половини ХХ ст. між селянами українцями та селянами росіянами.

На прикладі розглянутого питання ми маємо змогу простежити, як одна й та сама подія характеризується різними авторами мемуарів у залежності від їх особистих поглядів, переконань та уявлень. Авторська суб'єктивність $є$ незмінною рисою, що характеризує розглянуті матеріали незалежно від виду історичного джерела.

Загалом масив селянських мемуарних джерел у питанні вивчення подій Голодомору 1932-1933 років в Україні ми можемо розподілити на чотири групи:

- Допоміжні мемуарні джерела. До даної групи відносимо селянські щоденники і спогади, автори яких хоча й описують події 1932-33 рр., проте про Голодомор згадують лише поверхово, або повністю обходять дане питання. Замовчування питання голоду даними авторами пояснюємо відсутністю у них будь-якої інформації щодо розглянутої проблеми, або фактором самоцензури (як приклад - спомини Діани Авраменко, Івана Ярошенка). Можливе використання як допоміжних матеріалів, можуть виступати в якості джерел, що дозволяють уточнити соціальні відносини у процесі відтворення духу досліджуваної епохи;

- Особові джерела, що висвітлюють події Голодомору в руслі офіційної лінії комуністичної партії. Мемуарні джерела даної групи повторюють офіційні радянські штампи, про посуху, неврожай, намагаються не згадувати про смертельні випадки внаслідок масового голоду. Дозволяє дослідити зміни офіційних державних трактовок, встановити впливи радянської освіти на людину й офіційної державної ідеології. Прослідкувати ступінь самоцензури під впливом радянської репресивнототалітарної системи (Дмитро Коншин, Михайло Сіньков);

- Мемуарні джерела авторів інакодумців. Автори в яких простежуються антибільшовицькі настрої, викладають матеріал з намаганням привести максимум їм відомих подій, намагаються визначити причини Голодомору та вказати винних у трагедії. Дозволяють комплексно досліджувати Голодомор 1932-1933 років, встановлювати причино-наслідкові зв'язки трагедії у розумінні селянства, вияв- 
ляти фактологічний матеріал, як-то: імена загиблих від голоду, місця поховання й ін. (Михайло Алексєєв, Сергій Сало, Микола Молодик);

- Особові джерела інших соціальних верств. Яскравим прикладом є щоденник Дмитра Заволоки. Будучи державним службовцем і проживаючи у місті, він походить з селянської родини та підтримує родинні зв'язки з людьми, що мешкають у сільській місцевості. Мемуари даного типу дозволяють вскривати нові пласти як фактичного, так і емоційно-психологічного типу; проводити порівняльний аналіз із селянськими мемуарними джерелами; простежити еволюційні зміни у свідомості людини при переході з однієї соціальної групи до іншої.

Окремо маємо звернути увагу на необхідність при проведенні компаративного аналізу селянських мемуарних джерел розподіляти їх на дві додаткові групи: мемуари-літописи та мемуари-спогади. Адже у даному розгляді ми простежуємо досить суттєві відмінності у викладені матеріалу між цими категоріями джерел. Основні особливості у нашому випадку відносяться до глибини аналізу подій авторами мемуарів у зв'язку з отриманими ними пізніше від описаної події інформації та життєвого досвіду.

В умовах росту уваги до місця окремої особи в історичних подіях і вивчення впливів часу на свідомість людини мемуарні джерела становлять найбільшу цікавість. Одним з факторів, що дозволяє дослідити питання розвитку людської свідомості та розуміння власного місця особи у суспільстві $\epsilon$ аспект самоцензури авторів. На прикладі селянських мемуарних джерел XX ст. ми можемо простежувати як зміни ступеня самоцензури, так і певну консервацію у підходах до викладення матеріалів селянськими авторами. Таким чином, у нас виникає можливість проведення додаткового аналізу у напрямку вивчення факторів, які впливали на особу в рамках певної соціальної групи у питанні формування самосвідомості людини.

Розглянуті селянські мемуари становлять унікальне історичне джерело, яке дозволяє досліджувати події Голодомору 1932-1933 років з перших рук від людей, які стали безпосередніми жертвами даної трагедії. Селянська мемуаристика містить у собі цінні фрагменти історичних спостережень, віддзеркалює симпатії й антипатії авторів, їх погляди, оцінки, спостереження, душевні страждання та дозволяють більш чітко зрозуміти атмосферу, яка панувала на селі у ті часи. Селянські мемуарні джерела містять ту інформацію, яку неможливо віднайти в офіційних джерелах. Вони дозволяють нам по новому поглянути на специфіку відносин «маленької людини» із тоталітарним більшовицьким режимом, краще зрозуміти селянське мислення та буття середини минулого століття.

\section{REFERENCES}

Alieksieiev, O. (2009). «Orikhivska sprava $v$ doli moiei rodyny» [The Orikhiv case is the fate of my family]. Zaporizhzhia [in Ukrainian].

Bilivnenko, S. \& Moldavska, T. (Comp.). (2014). Salo Serhii. Spohady (1899-1946 rr.) [Salo Sergii. Memoirs (1899-1946)] (Seriia «Starozhytnosti Pivdennoi Ukrainy», Vol. 24). Kyiv [in Ukrainian].

Boiko, A. \& etc. (Comp.). (2006). Memuary ta shchodennyky (Dzherela z istorii Pivdennoi Ukrainy) [Memoirs and diaries (Sources on the history of Southern Ukraine)]. Vol. 9. Zaporizhzhia [in Ukrainian].

Boriak, T. (Comp.). (2016). «I choho vy shche zhyvi?» [«And why are you still alive?»]. Kyiv: TOV «Vydavnytstvo «Klio» [in Ukrainian].

Borodin, Ye.I. (Ed.). (2008). Natsionalna Knyha pam'iati zhertv Holodomoru 1932-1933 rr. v Ukraini. Dnipropetrovska oblast [National Book of Remembrance for the Victims of the Holodomor of 19321933 in Ukraine. Dnipropetrovsk region]. Dnipropetrovsk: ART-PRES [in Ukrainian].

Conquest, R. (1993). Zhnyva skorboty. Kolektyvizatsiia i holodomor [The harvest of sorrow. Collectivi- 
zation and the Holodomor]. Kyiv [in Ukrainian].

Danylenko, V.M. (Comp.) (2010). Holodomor 1932-1933 rr. v Ukraini za dokumentamy HDA SBU: Anotovanyi dovidnyk [Holodomor of 1932-1933 in Ukraine according to the documents of the Sectoral State Archive of State Security Service of Ukraine: Annotated reference book]. Lviv: Tsentr doslidzhen vyzvolnoho rukhu [in Ukrainian].

Danylenko, V., Kas'ianov, G. \& Kulchytskyi, S. (1991). Stalinizm na Ukraini: 20-30-ti roky [Stalinism in Ukraine: 1920-30th]. Kyiv [in Ukrainian].

Dnevniki i zapisi [Diaries and notes] (N.d.). Sait «Prozhyto». Retrieved from: https://www.prozhito.org

Faizulin, Ya. (Ed.) (2018). «Represovani» shchodennyky. Holodomor 1932-1933 rokiv v Ukraini [«Repressed» diaries. The Holodomor of 1932-1933 in Ukraine]. Kyiv: Feniks [in Ukrainian].

Faizulin, Ya. (2017, November, 30). Shchodennyk uchytelia, za yakyi daly 10 rokiv taboriv [Teacher's Diary, for which they gave 10 years of camps]. Gazeta.ua. Retrieved from: https://gazeta.ua/articles/events-journal/_sodennik-uchitelya-za-yakij-dali-10-rokivtaboriv/805029 [in Ukrainian].

Kapustian, G. (2009). Otsinka Holodomoru 1932-1933 rr. v Ukraini v dokumentakh usnoi istorii [Estimation of the Holodomor of 1932-1933 in Ukraine in oral history documents]. Abstracts of Papers: Holodomor 1932-1933 rokiv v Ukraini: prychyny, demohrafichni naslidky, pravova otsinka, (pp. 169189). Kyiv [in Ukrainian].

Konshyn, D. (2008). Rasskaz o svoei zhyzni... [A story about my life...]. Zaporizhzhia [in Ukrainian].

Liubovets, N. (2010). Vyvchennia memuariv yak istorychnoho ta biohrafichnoho dzherela: do istoriohrafii problem [The study of memoirs as a historical and biographical source: to the historiography of the problem]. Ukrainska biohrafistyka, 7, 66-104 [in Ukrainian].

Mase, J. (2004). Politychni prychyny Holodomoru v Ukraini (1932-1933 rr.) [Political causes of the Holodomor in Ukraine (1932-1933)]. Retrieved from: http://ekmair.ukma.edu.ua/handle/123456789/447 [in Ukrainian].

Marochko, V. (2007). Holodomor 1932-1933 rr. [Holodomor of 1932-1933]. Kyiv [in Ukrainian].

Milchev, V. \& Iriohlu, Y. (2008). «Usni istorii» tavriiskykh bolhar yak dzherelo doslidzhennia holodomoriv 1932-1933 ta 1946-1947 rokiv [«Oral stories» of Taurian Bulgarians as a source of research on the Holodomors of 1932-1933 and 1946-1947]. In Holodomor 1932-1933: zaporizkyi vymir, (pp. 208-230). Zaporizhzhia [in Ukrainian].

Pyrih, R.Ya. (Comp.) (2007). Holodomor 1932-1933 rokiv v Ukraini: dokumenty i materialy [The Holodomor of 1932-1933 in Ukraine: documents and materials]. Kyiv: Vyd. dim «Kyievo-Mohylianska akademiia» [in Ukrainian].

Shapoval, Y. (2006). Holodomor 1932-1933: vtrata ta vynaidennia [The Holodomor of 1932-1933: losses and finds from public archival documents]. Dzerkalo tyzhnia, 44, 21 [in Ukrainian].

Turchenko, F. (2008). Piznaty pravdu... [Learn the truth...]. In Holodomor 1932-1933: zaporizkyi vymir, (pp. 6-22). Zaporizhzhia [in Ukrainian].

Turchenko, F.H. (Ed.). (2008). Natsionalna Knyha pam'iati zhertv Holodomoru 1932-1933 pp. v Ukraini. Zaporizka oblast [National Book of Remembrance for the Victims of the Holodomor of 19321933 in Ukraine. Zaporizhzhia region]. Zaporizhzhia: Dyke Pole [in Ukrainian].

Verstiuk, V., Tylishchak, V. \& Yukhnovskyi, I. (2008). Henotsyd ukrainskoho narodu 1932-1933 [Genocide of the Ukrainian people 1932-1933]. Kyiv [in Ukrainian].

Veselova, 0. (2003). Ukrainski zbirnyky dokumentiv i materialiv z pytan holodomoru. Holod 1932-1933 rokiv v Ukraini: prychyny ta naslidky [Ukrainian collections of documents and materials on the Holodomor. The famine of 1932-1933 in Ukraine: causes and consequences]. Kyiv: Naukova Dumka [in Ukrainian].

Yakovliev, I.0. (Ed.). (2008). Natsionalna knyhy pam'iati zhertv Holodomoru 1932-1933 rokiv v Ukraini. Khersonska oblast [National Book of Remembrance for the Victims of the Holodomor of 1932-1933 in Ukraine. Kherson region]. Kherson [in Ukrainian]. 


\section{Oleksii Alieksieiev}

(Zaporizhzhia National University, Zaporizhzhia, Ukraine)

e-mail: oleksijalekseev79@gmail.com

ORCID: https://orcid.org/0000-0002-5142-1484

\section{Issue of Authenticity of Peasant Memoirs Describing Holodomor of 1932-1933}

In the offered paper the issue of reliability of the information stated in peasant memoirs concerning events of Holodomor of 1932-1933 in Ukraine is considered. The level of possibilities for processing peasant memoirs as an independent historical source in complex historical researches is studied. Factors influencing the authenticity of memoirs are determined: selfcensorship, aberrations of various kinds, the influence of the social and cultural environment, etc. The scheme of classification of peasant memoir sources by groups according to their internal features and signs is offered.

Four groups of peasant personal sources are identified, depending on their information capabilities in studying of Holodomor of 1932-1933 in Ukraine issues. The peculiarities of peasant memoirs and trends of their further study are determined for each of the proposed groups. The conditions in which peasant memoir sources appear are analyzed.

According to the results of a comparative analysis of peasant memoirs and data from The National Memory Book of Holodomor Victims 1932-1933 in Ukraine, several new names are identified that are absent in the previously collected information and need to be included in The National Memory Book.

The studied peasant memoirs are a unique historical source, which allows to studying the events of Holodomor of 1932-1933 at first hand, from people who were the direct victims of the tragedy. Peasant memoirs contain valuable fragments of historical observations, reflect the likes and dislikes of the authors, their views, assessments, observations, distresses of soul, and allow a clearer understanding of the atmosphere that prevailed in the village at that time.

Using of peasant memoirs in the study of Holodomor gives the opportunity to distinguish a new layer of historical information from the direct participants in the events of the famine of 1932-1933. Such evidence adds authenticity to the image of history and allows to trace the effects of Soviet education and propaganda on the individual and allows us to take a fresh look at the specifics of the little man's relationship with the totalitarian Bilshovyk regime, and better understand peasant thinking and mid-20 $0^{\text {th }}$ century life.

Keywords: Ukraine, USSR, grain procurement, Holodomor of 1932-1933, historical sources, memoirs, peasants, collective farmers 